\section{“Kör Keçi”den “Körebe”ye: Oyun İçinde Oyun*}

\author{
Pınar Kasapoğlu Akyol ${ }^{1 * *} \odot$, M. Muhtar Kutlu² \\ 'Dr. Öğr. Üyesi | Ankara Üniversitesi, Dil ve Tarih - Coğrafya Fakültesi, \\ Halkbilim Bölümü, Ankara / TÜRKIYE \\ ${ }^{2}$ Prof. Dr. | Ankara Üniversitesi, Dil ve Tarih - Coğrafya Fakültesi, \\ Halkbilim Bölümü, Ankara / TÜRKIYE
}

** Sorumlu Yazar / Corresponding Author: Pınar Kasapoğlu Akyol Ankara Üniversitesi Dil ve Tarih - Coğrafya Fakültesi Halkbilim Bölümü, Halkbilim Anabilim Dalı 06100 Sıhhiye, Ankara / TÜRKIYE E-posta: pkasapoglu@ankara.edu.tr

\section{$\ddot{O} z$}

Çocuğun / çocukluğun toplumsal-kültürel tarihini yeniden inşa etmede tarihsel ve kültürel yorumun en çok başvurduğu belge ve nesneler içinde çocuk oyunlar ve oyuncaklar gelmektedir. Anadolu'nun tüm yörelerinde yapılmış çocuk oyunlarına ilişkin derleme ve monografi nitelikli çalışmalarda karşımıza çıkan körebe oyunu da köklü bir geçmişe ve geniş bir coğrafi dağılıma sahip bir oyundur. Oyun kuralları, alanı, zamanı ve oyun örgüsüyle çok bildik ve çok tanıdık bir çocuk oyunudur. Cinsiyet ayrımı yapılmaksızın, iç ya da dış mekânlarda, belirlenmiş alanlarda (kimi zaman bir çember, kimi zaman bir oda) oynanan geleneksel çocuk oyunları sınıflamaları içinde yer alan kurall grup oyunlarından biridir. Oyunun Anadolu çeşitlemelerinde içeriği ve temel özellikleri çoğunlukla değişmemektedir. Oyuna, çocuk oyunlarında ebenin rolü açısından bakıldığında; oyuna adını veren körebe olumsuz ve cezalandırılmış bir rolde kaybedendir. Oyun, yeni kaybedenleri bulmak üzere sürer ve hiç ebe olmayan oyuncu, oyunun kazananıdır. Çoğu çocuk oyununun kökenlerinin arkaik dönemin ritüelistik uygulamalarından türediği, onların izlerini taşıdığı ya da üstü örtük de olsa günümüze uzanmış öğelerle sürdürüldüğü bilinir. Oyunun betimlemeye çalıştığımız bu hali ile ritüel öğelerle ilișkilendirilmesi zor görünmektedir. Acaba öyle mi? Bu makalede, dünyanın birçok yerinde kör keçi olarak adlandırılan ve Anadolu'nun bazı bölgelerinde de kör çepiç olarak bilinen körebe oyununun, toplumsal bellekte saklı bir ritüel kalıntısı olduğunu gösteren izler üzerinden tartışılmaya çalışılacaktır.

Anahtar Sözcükler: Oyun, çocuk oyunu, körebe, kör keçi, ritüel

\section{Giriş}

Çocuğun/çocukluğun toplumsal-kültürel tarihini yeniden inşa etmede tarihsel ve kültürel yorumun en çok başvurduğu belge ve nesneler içinde çocuk oyunlar ve oyuncaklar gelmektedir. Oyun ve oyuncağa bakmak; aynı zamanda çocuğa, çocukluğa ve çocuk

* Gaziantep Üniversitesi'nde düzenlenen "Halk Kültüründe Oyun Müzik Dans Uluslararası Sempozyumu"nda (17- 19 Ekim 2019) sunulan sözlü bildirinin gözden geçirilip genişletilerek makaleye dönüştürülmüş şeklidir.

\section{From "Blind Goat" to "Körebe": The Game within the Game} Abstract

In reconstructing the socio-cultural history of the child / childhood, children's games and toys are among the most frequently used documents and objects of historical and cultural interpretation. Körebe (blind man's bluff) is one of the children's games with a long history and a wide geographical distribution which is encountered in qualified works such as compilation and monographs on children's games in all regions of Anatolia. The compilation and monographs of children's plays made in all regions of Anatolia, which are encountered in the quality of the game, körebe is a game with a long history and a wide geographical distribution. Körebe is a very familiar children's game with its pattern, rules, areas and time. It is one of the regular group games that take place in the traditional classifications of children's games, which are played indoors or outdoors, in designated areas (sometimes a circle, sometimes a room), regardless of gender. The content and basic characteristics of the play in Anatolian variations are mostly unchanged. The game, in terms of the role of the ebe in children's games; körebe who gave his name to the game is the loser in a negative and punished role. The game continues to find new losers and the player who has not become the ebe is the winner. The origins of most children's plays are known to derive from the ritualistic practices of the archaic period, bears traces of them, or continue with implicit elements that have survived to the present day. It seems difficult to relate to the ritual elements in this state of körebe game that we try to describe. Is that so? In this paper, we will try to discuss on the traces of the game which is called blind goat in many parts of the world and which is known as kör çepiç in some parts of Anatolia, is a ritual remnant bidden in social memory.

Key Words: Game, children's game, blind man's bluff, blind goat, ritual

kültürüne bakmak anlamına gelir. Çocuklar oyun ve oyuncaklarıyla -yetişkinlerin onlar için yarattıkları dışında- kendi kültürlerini de yaratmaktadırlar.

Oyunun kültürel anlamı ve işlevi açısından oyun kavramı konusunda ufkumuzu açan Johan Huizinga, o güne kadar (1938) insanı nitelemek için kullanılan terimlere eklediği Homo Ludens (oyun oynayan insan) kavramiyla; döneminde modernitenin oyunu küçümseyici tutumuna karşı önemli bir karş1 çıkışı gerçekleştirmiş ve oyunu yaklaşık olarak şöyle tanımlamıştır: 


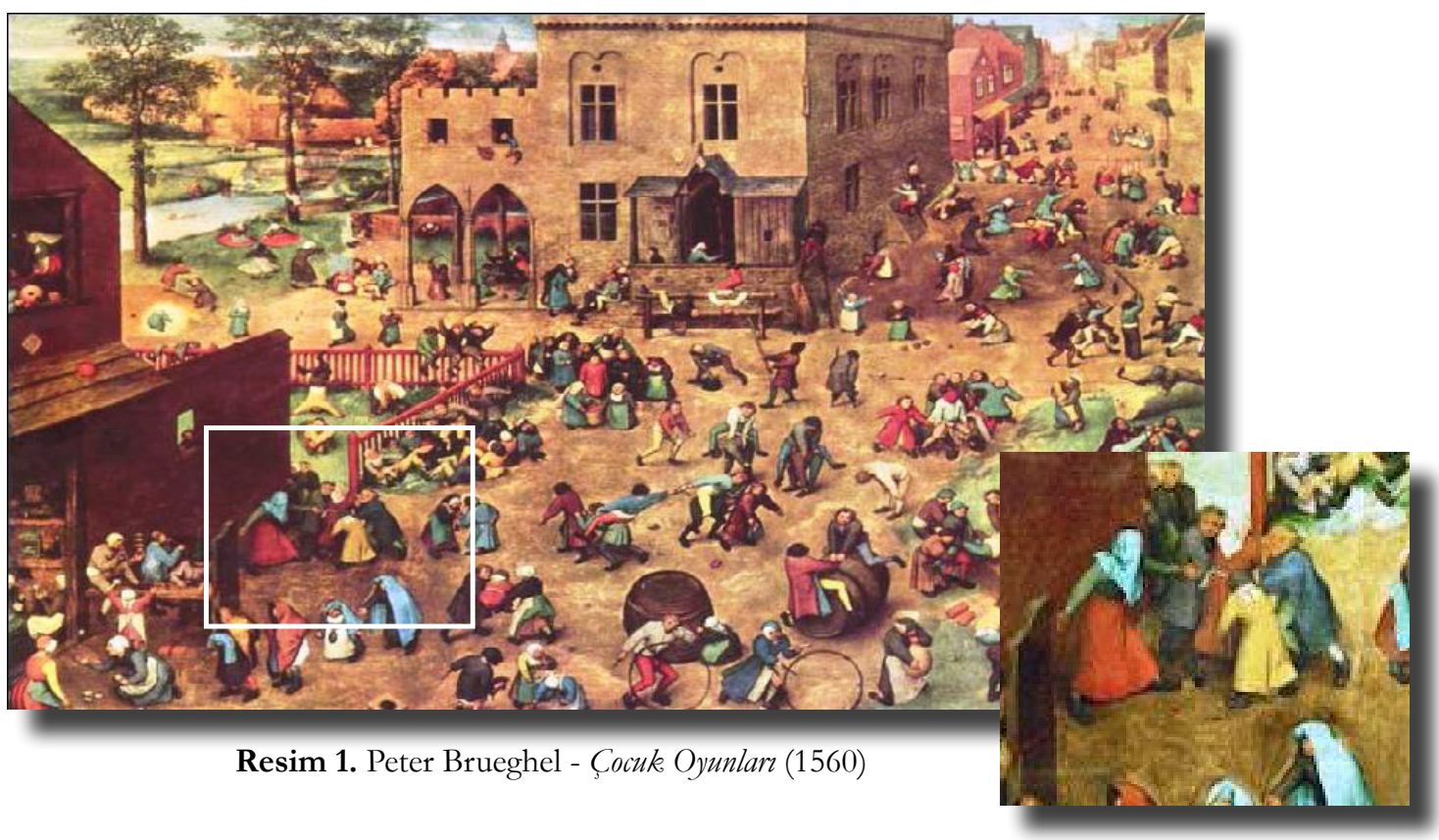

Resim 2. Körebe Oyunu

\begin{abstract}
"Oyun, özgürce razı olunan ama tamamen emredici kurallara uygun olarak belirli zaman ve mekân sınırları içinde gerçekleştirilen, bizatihi bir amaca sahip olan, bir gerilim ve sevinç duygusu ile 'alışılmış hayat'tan "başka türlü olmak" bilincinin eşlik ettiği, iradi bir eylem veya faaliyettir." (Huizinga, 1995, s.
\end{abstract} 48)

Görüldüğü gibi oyuna içkin özelliklerin başında; "belli bir yer, zaman, sinırlar ve düzen içinde, uyulmasına rıza gösterilmiş kurallarla belli bir yarar ve gereklilik dışında gerçekleşen bir faaliyet olması" gelmektedir (Huizinga, 1995, s. 171).

Oyunun insanın varlı̆̆ı ve kültürü açısından yerinin anlaşılması, genel oyun kavramından ayr1 düşünemeyeceğimiz çocuk oyunlarına bakış açımıza yeni boyutlar katmıştır. Oyun kavramının önemli incelemecilerinden biri olan Roger Caillois ise Huizinga'dan esinle oyunun önemli ve ciddi bir etkinlik olduğunu, oyun ve oyuncağın tarihin akışı içinde kültürün kalıntıları olduğunu söyleyerek bugün önemsiz görülen kimi oyunların, eskiden dinsel ve dindışı önemli kurumların ayrılmaz bir parçası olduğuna dikkat çeker. Zamanla toplumsal işlevleri değişen ama doğaları aynı kalan çocuk oyunlarının da incelendiğinde oyunun doğasına ulaşılabileceğini ileri sürer (And, 1979).

Bu çalışmada bir anlamda bu yolu izleyerek evrensel niteliği ve Anadolu'nun tüm yörelerinde yaygın ve tipik özellikleriyle karşımıza çıkan bir çocuk oyunu olan körebe oyununun doğasını ritüel kökeni üzerinden anlamaya çalışacağız. Ritüel ya da ayini, "içsel tutarlılığ1 olan, sistemleştirilmiş ve genellikle bir mitos ya da gizemleştirilmiş bir tarihin yeniden canlandırılmasına yönelik ritler süreci” ve simgesel anlamlarla yüklü eylemler olarak tanımlamak mümkündür (Özbudun, 1997). V. Turner, ritüellerin sadece mistik bir anlamı olduğuna ve ibadet biçimi/pratiği gibi görünmesine karş1 çıkarak, "ritüellerde sergilenenleri görmek, izlemek kadar, o hareket ve sözcüklerin onlar için ne anlam taşıdığını anlamak önemlidir" derken ritüelin simgesel anlamlarına dikkat çeker (Turner, 2018, s. 18). Körebe oyununun ritüel kökenlerini ararken bir ritüelin sadece dini değil, toplumsal içerikli anlamlı simgelerden oluştuğunu ve yorumlanması gerektiğini aynı zamanda ritüel-oyun ilişkisini görmemiz gerekir. Bu çabamızı bir "oyun etnografisi” olarak da niteleyebiliriz.

\section{Körebe Oyununun Yerel ve Evrensel Görünümü}

Körebe oyиnu evrensel bir oyundur. 16. yüzyllin en büyük ressamlarından biri olan Pieter Brueghel'in, 1560 yılında yaptığı, 91 adet bilinen ve farklı çocuk oyunun resmedildiği "çocuk oyunları" adlı tablosunda yer alan bir oyundur (Resim 1,2). Etnografik bir belge niteliğinde olan resmin evrensel çocuk oyunlarının görsel bir ansiklopedisi olduğu ileri sürülmüsstür.

Oyunun köklü geçmişiyle Anadolu'da da geniş bir coğrafi dağılıma sahip olduğu da görülür. Oyun kuralları, alanı, zamanı ve oyun örgüsüyle çok bildik ve çok tanıdık bir çocuk oyunu olan körebe, halkbilim araştırmaları içinde neredeyse tüm yörelerde yapılmış çocuk oyunlarına ilişkin derleme ve monografi nitelikli çalışmalarda karşımıza çıkmaktadır. $\mathrm{Bu}$ oyunun geleneksel çocuk oyunları sınıflamaları içinde yerini almış bir oyun olduğunu da biliyoruz. Örneğin, M. And'ın oyun sinıflaması içinde "Koşma-Kovalama-Kurtarma-Zor Kullanma Oyunlar' kümesinde yer almaktadır (And, 2012, s. 269).

Kız ve erkek çocuk ayrımı yapılmaksızın, iç ya da 
dış mekânlarda, belirlenmiş alanlarda, kimi zaman bir çember, kimi zaman bir odada oynanan kurall grup oyunlarnndan biridir. Çocuk oyunlarının sözel dağarcı̆̆ında önemli bir yeri olan sayışmaca ve tekerlemeler ebenin seçiminde ve oyun sırasında bu oyun için de geçerlidir. Oyunun Anadolu çeşitlemelerinde içeriği ve temel özellikleri çoğunlukla değişmemektedir. Önce ebe belirlenir ve ebenin gözleri bir bezle bağlanır. Oyun adını buradan almaktadır. Ebe ortada kalacak biçimde oyuncular etrafinda bir halka oluşturur. Oyuncular halkay1 bozmadan el çırparak ebenin çevresinde dönerler. Ebe bu sırada kollarını öne doğru uzatarak dokunduğu kişinin başını, yüzünü ve üstünü elleriyle yoklar. Kim olduğunu anlayabilirse adını söyler. Eğer tanırsa, dokunduğu oyuncu ebe olur. Tanıyamazsa, oyun aynı ebeyle sürer. Oyuna çocuk oyunlarında ebenin rolü açısından bakıldığında, oyuna adını veren körebe olumsuz ve cezalandırılmıs bir rolde kaybedendir. Oyun, yeni kaybedenleri bulmak üzere sürer ve hiç ebe olmayan oyuncu, oyunun kazananıdır.

Çoğu çocuk oyununun kökenleri konusunda arkaik dönemin ritüelistik uygulamalarından türediği, onların izlerini taşıdığı ya da üstü örtük de olsa günümüze uzanmış öğelerle sürdürüldüğü bilinir. Oyunun betimlemeye çalıştığımız bu hali ile ritüel öğelerle ilişkilendirilmesi ilk bakışta zor görünmektedir. Acaba öyle mi?

Bu konuda ilk ipucu oyunun adında saklıdır. Yaygin adıile körebeoyunu Anadolu'nunçok farklıyerlerinde farklı adlarla da bilinmektedir: Kırklareli'nde Kör Çapar Oyunu, Çorum köylerinde Körebe (Gö̧̋bağlama), İzmir/Tire'de Körlebbek, İstanbul/Çatalca'da Sin Gitti, Safranbolu'da Ebe Kusk $\imath_{3}$ (burada ebenin yakalaması yetmez, kim olduğunu elleyerek bilmesi gerekir), Azerbaycan'da Miyancı ve Cömçebaşı Bez̧eme (oldukça değişiktir, bir kukla ve çıngırak da vardır) ve yine Azerbaycan'da Gözbağlayıcı, Kayseri'de Bir Kör İki Kör vb. Ilgın'da oynanan Depmetura Oyunu'nda hem körebe gibi gözleri bağlı olarak arama eylemi vardır, hem de saldırı ve savunma gibi başka eylemler bulunur. Toroslar, Akşehir, Sultan Dağlarr'nda Avşar oymaklarının oynadığı Turna Oyunu da türkülü bir körebe oyunudur (And, 2012). Ayrica, Yozgat Darıca köyünde Ebe-Virrke, Isparta'da Ebelebel, CelepÇatalca'da Singitti olarak adlandırılmaktadır (Eren, 1984). Bunlara ek olarak, Manisa'da Kör Tilki, Kirşehir'de Göz Bağlamaç, Çorum'da Göz Bağlama, Isparta'da Kalem Oyunu ve Tekirdağ’da İ İ̧inde Gözbağ adlarına rastlanmaktadır (Özdemir, 2006).

Ne var ki sadece üç yerde; Ula/Muğla (Demircioğlu 1934), Ankara (Koşay, 1934) ve Balıkesir'de (Özdemir, 2006) oyunun adı diğerlerinden belirgin bir farklılıkla keçi ve keçi yavrusu olan şepiç/çebişs ${ }^{1}$ ve teke ${ }^{2}$ ile

${ }^{1}$ Çepiç: Bir yaşındaki keçi yavrusu (Türkçe Sözlük, 2005, s. 405).

${ }^{2}$ Teke: Erkek Keçi (Türkçe Sözlük, 2005, s. 1935). ilişkilendirilerek körkeçi, körçepiç / körçebiş ve körteke adlarıyla karşımıza çıkmaktadır.

Çocuk oyunları üzerine oldukça erken dönem derleme çalışması olan Yusuf Ziya Demircioğlu'nun (1934) Anadolu'da Eski Cocuk Oyunlar adlı çalışmasında Muğla'ya bağlı Ula'dan derlediği altmış oyun içinde körebe oyunu kör çepiç adıyla yer almakta ve şöyle tanımlanmaktadır:

\begin{abstract}
“Oyuncular evvela göz göz ederler. Bunlardan biri eline bir boncuk, ufak bir taş parçası yahut bir yüzük alır. Göz göz diye karşısındakine gösterir, sonra ellerini arkasina götürerek bunu avucunun birine kor. Avucunu yumarak karşısındakinin önüne tutar. Karşısındaki boncukla taşın saklanan şey ne ise onun bulunduğu avucu açtırırsa güdek ona geçer. Bunun bir falı, tekerlemesi de vardir. Oyuncu dolu avucu bilmek ve bulmak için: Biricik, ikicik, üçcük..../ Kara Tavuk kancık/ Ondadır Bundadır, helvacının kızındadır der ve son kelimenin rasgeldiği yumruğu açtırmaz. Ötekini açtııır. Ĕğer güdeği alırsa o da aynı taşı evvelki gibi saklayıp diğer oyunculara güdeği satmak ister. Böylelikle bütün oyuncular güdek devresinden geçer. En son güdek kimde kalırsa o güdekçi (=ebe) olur. Güdekçinin gözleri, mendil, yazma gibi bir şeyle hiç göremeyecek bir halde bağlanır. Öteki oyuncular evin içinde öteye beriye kaçışmaya, dolaşmaya başlarlar. Güdekçi kulağı ile hissi ile oyuncuların bulundukları yeri, semti bulup onları tutmağa çalışır. Kimi yakalarsa güdek ona geçer onun gözleri bağlanır, oyun böylece devam eder." (Demircioğlu, 1934, s. 35-36)
\end{abstract}

Yine, H. Z. Koşay'ın (1935) Ankara Budun Bilgisi adlı çalışmasının "Çocuk Oyunları" bölümünde oyun körçebiş adıyla derlenmiştir. Koşay, oyunu "Ebenin gözünü yimeni ile bağlarlar. Herkes dürtekler, Körçebiş kaklıda dıvara yapış diyi bağrışırlar, o da kollarını aça aça arar tuttuğu adamı ebe yaparlar" şeklinde açılamaktadır (Koşay, 1935, s. 280). And (1979) çebişin keçi yavrusu olduğunu, tepesindeki saçları gözlerinin üstüne düştüğünden körebe oyunundaki gözleri bağlı ebeye benzetilmesi nedeniyle oyuna bu ad verildiğini söyler.

Ayrıca, yakın dönem derleme çalışmaları içinde Ali Abbas Çınar'ın (2007) Muğla ve Akyaka çalışmalarında oyunun körçebiç adıyla derlendiğini görürüz. Kaynak kişi, oyunun dişarıda oynandığında çizilen bir çember (daire) içinde oynandığını, çemberin dışına çıkanın ve ebe tarafindan yakalananın yeni ebe olduğunu belirtmektedir.

Benzer biçimde adlandırmaya Anadolu dışından bir örnek ise, Mevlüt Özhan ve Malik Muradoğlu'nun (1997) Türk Cumburiyetlerinde Cocuk Oyunları çalışmasinda yer almaktadır. Oyun, Kırgızistan ve Kazakistan'da kör teke / sokur teke $e^{3}$ adıyla bilinmekte ve şu şekilde

${ }^{3}$ Sokur: Bir gözü kör hayvan (Türkçe Sözlük, 2005, s. 1787). 
açıklanmaktadır:

\begin{abstract}
"Açık alanda kalabalık oyuncu grubuyla oynanır. Bir araya toplanan çocuklar bacaklarını uzatarak yan yana otururlar. Hapsi birlikte diz kapaklarını ovmaya başlar ve hepsi 'ov ov ov' diye bağırır. Bir süre sonra hepsi birden ayağa kalkmak için sıçrarlar. Bu sıçrama sırasında ayağa kalkamayan oyuncunun gözleri bağlanır. Gözü bağlı oyuncu etrafa kaçışan oyuncuları tutmaya yakalamaya çalışır. Tuttuğu oyuncunun kim olduğunu bildiği takdirde (ismini söyler) yakalanan oyuncu sokur teke olur. Onun gözleri bağlanarak oyuna devam edilir. Bilemezse aynı oyuncunun sokur tekeliği sürer." (Özhan ve Muradoğlu, 1997, s. 66).
\end{abstract}

Bu kaynaklarda da görüldüğü gibi, sonuçta körebe oyunu kör keçi, kör çebiç ya da kör teke/ sokur teke adlariyla Anadolu'da yaşamaktadır.

M. And, Anadolu oyunlarında, yeryüzünde yayılmış oyunların hemen hepsinin benzerlerini ve çeşitlemelerini bulmanın mümkün olduğunu söyledikten sonra, Anadolu'da körebe oyununun benzerleri olarak, İsveç, Danimarka ve Güney Almanya'da kör keçi anlamına gelen sözcüklerle ifade edilen oyunlar olduğundan söz eder. Bu oyuna İsveç'te blind bock, Danimarka'da blindebuk denilmektedir ve her ikisi de kör keçi anlamına gelmektedir. Almanlar ise körebe oyununu blinde kub (tr. kör inek) ya da blind bock (tr. kör keçi) diye adlandirırlar (And, 1979). Güney Almanya'da kör keçi oyununda kör kę̧i olan ebenin gözleri bağlı iken kimin alnına iki kez değebilirse, değdiğine "yandı" denilir. Yine And'ın açıklamalarına göre, eski kurban ritüellerinde rahibin hayvan postu giyerek, gözleri bağlı halde, rastlantı ile elinin değdiği kişinin ateşte kurban edilmesi ile bu oyun yakından ilişkilendirilir. Ritüelde hayvan postu giymek, oyunda kör keçi olmak, her ikisinde de gözlerin bağlanması, rastlantı ile değdiğinin ritüelde gerçekten yanması, oyunda ise sözle yanması gibi ortak noktalar ister istemez oyunun bu türden bir ritüelin kalıntıs1 olduğu görüşünü pekiştirmektedir (And, 1979).

\section{"Kör Keçi"den "Körebeye"}

M. And'ın araladığı bu kapıdan girmeden önce, oyun adından yola çıkarak yeni izler ya da işaretler bulmak mümkündür. Bu konuda keçi figürü dikkat çekicidir. İlk evcilleştirilen hayvanlardan biri olarak bilinen keçi, Antik Misır'dan Antik Yunan'a ve çeşitli kimlikler, suretler ve adlar altında Anadolu kültürünün de binlerce y1llık ayrılmaz bir parçası olmuştur ${ }^{4}$. Ya eril bir üretkenliğin ya da bir kurbanın simgesi olan keçi, tiyatro sanatının kökenini açıklamaya yönelik tezler içinde Dionisos şenlikleriyle başlayan, keçi ayaklı ve teke derileri giyen satir korosunun söylediği şarkılardan doğan tragedyanın, keçilerin ezgisi (tragos oidie) anlamına geldiği

${ }^{4}$ bkz. Oyal, 2013. ileri sürülmüştür. Çok tanrılı dinlerin ve mitosların da başkahramanı olan keçi, çoğu kez tanrıların kılığında karşımıza çıkmaktadır. Başta Dionisos, yarı insan yarı keçi olan Pan ve Satir olmak üzere hep keçi k1lığında canlandırılmışlardır. Batı'da giderek olumsuz, uçarı ve özellikle şeytan imgesine dönüşen keçinin, Türk mitolojisinde İslam öncesi dönem dâhil, çoğunlukla dă keçisi motifiyle olumlu hatta sayg1 duyulan bir hayvan olduğu görülür (Oyal, 2013) . Dağ keçisinin/ tekesinin, damgalardan kurganlara, yazitlardan heykellere, desenlere, anlatılara kadar birçok yaratıda ortak bir simge olarak yer aldığı görülür. Anadolu Köy Seyirlik oyunlarına katılan hayvan benzetmelerinin başında keçi gelmekte, oyuncular ya keçi olmakta, ya da keçi postu giyinmiş keçi adamlara bürünmektedirler. Böylece, bilmeden tanrısalla doğrudan doğruya bağlantı kurulmuş olmaktadır (And, 1962). Bu nedenle, keçinin bu kadim kültürel mirasiyla körebe oyununda ebe olarak varlığı sıradan değildir.

Öte yandan yine Huizinga'dan esinle, oyunun doğas1 üzerine belirlenen temel öğelerden ${ }^{6}$ biri olan zaman kavramı açışından körebe oyununu değerlendirebiliriz. S. Cengiz, "oyun zamanının kendine özgü olduğu, oyun dışındaki zamanla oyun zamanının türdeş olmadığını" söyledikten sonra Eliade'nin (1991) "kutsal zaman" kavramına göndermede bulunur: "Bu bağlamda, oyun zamanının, Eliade'nin açıklamasını yaptığı kutsal zamandan bir fark1 yoktur. Eliade (1991, s. 64-70)' ye göre kutsal zaman tersine çevrilebilir bir zamandır ve bayramlar, şenlikler aracillğ 1 ile yllın belirli dönemlerinde [takvimsel/mevsimsel ritler] din dışı zamandan farklı yoğunluklarda tekrar tekrar yaşanmaktadır." (Cengiz, 1997, s. 59). Eliade'nin sözünü ettiğgi kutsal zaman kozmogonik mitoslardan kaynaklanan ritüellerle canlandırılmaktadır. Zamanın yeniden doğuşunu simgeleyen, yeni yil ayin ve törenlerinde bir önceki y1lin ve topluluğun günahlarını, kötülüklerini, hastalıklarını ve ifritlerini kovmak adına bir hayvan seçiliyordu. $\mathrm{Bu}$ hayvan çoğunlukla kurban olan keçi ya da keçi kılıklı, postlu, maskeli kişilerdi. Toplumun günahlarının yüklendiği düşünülen bu hayvanın, günah keçisi (en. scapegoat) ya da hayvan maskeli bir insanın simgesel olarak kovulması, yaşadığı bölge sınırlarının dışına ayinsel olarak gönderilmesi ile mümkün olmaktaydı. Günah keçisinin kovulması ayinsel bir arınma anlamina geliyor ve bu bir anlamda yeniden doğuşu da

\footnotetext{
${ }^{5}$ Anadolu göçer topluluklar içinde özellikle yörükler, halk inançları bağlamında koyunu melek, keçiyi ise şeytan olarak tanımlarlar (Aktan, 1996).

${ }^{6}$ Oyunun temel öğeleri dört tanedir: alan, zaman, kurallar ve amaç (bkz. Cengiz, 1997, s. 58).

${ }^{7}$ bkz. Frazer, 2017, s. 342.
} 


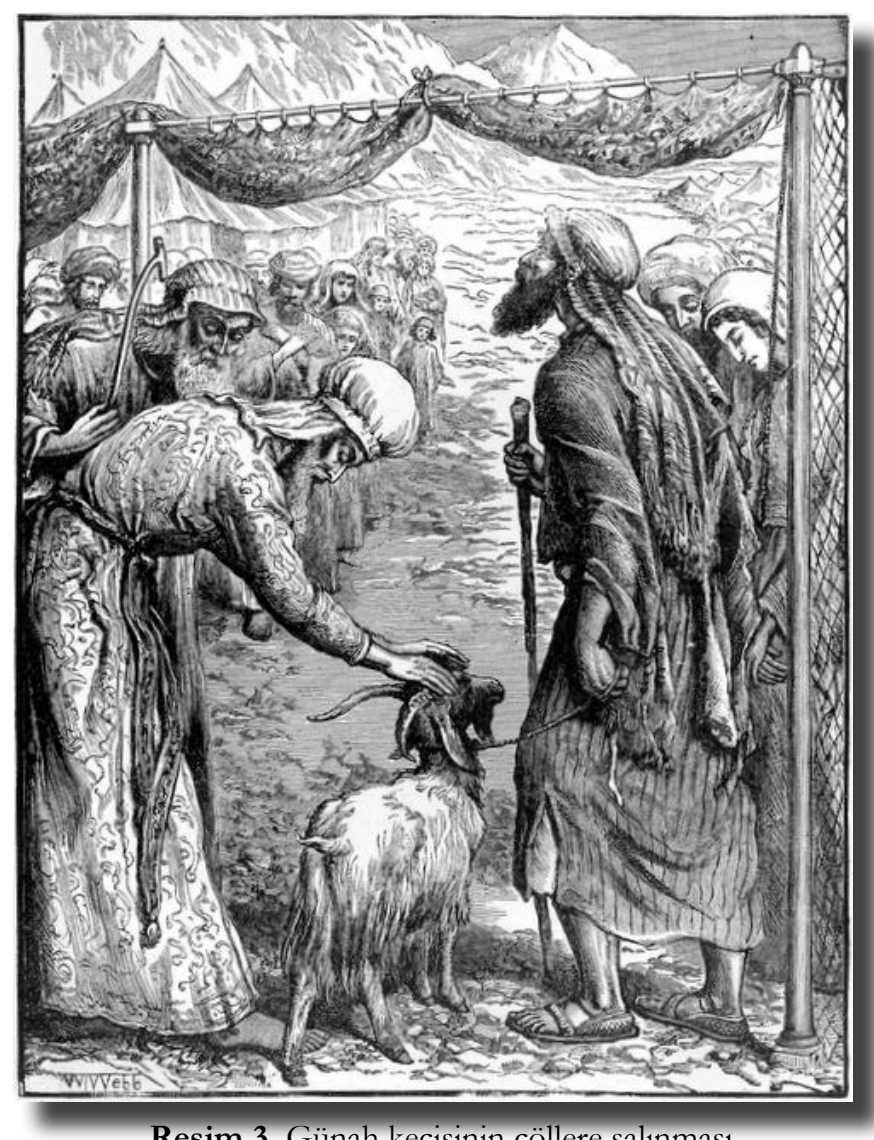

Resim 3. Günah keçisinin çöllere salınması

(Sending out the scapegoat, t.y.)

simgeliyordu ${ }^{8}$ (Eliade, 1976) (Resim 3). Eski Ortadoğu mitoslarından kaynaklanan günah keçisi kavramı da buradan gelmektedir. Körebe oyununda ebe tarafindan seçilmiş (yakalanmış) ve kaybetmiş olan kişinin, günah keçisi ile olan ilişkisini ilk anda akla getirmektedir.

Osmanlı şenliklerinde gördügümüz, keçi ayaklı ve ellerinde keçi derisinden tulumlarıyla şenlik alanını düzenleyen, şakalaşan ve oyuncuları taklit eden tulumcuları ${ }^{9}$ ve Yörük Türkmen topluluklarında keçi derilerine bürünmüş, üzerlerinde ziller, çanlar bulunan, başlarında deriden yapılmış başlıklarıyla keçi adamların oynadıkları tuluk oyun ${ }^{10} \mathrm{nu}$ bu geleneğin izleri olarak düşünülebiliriz (Yalman, 1993) (Resim 4, 5, 6).

Yine keçi figürünü köy seyirlik oyunlarında, bereket temalı kutlama ve şenliklere eşlik eden keçi postu giymiş "keçi adam"larla bugün de izlemeye devam ediyoruz (Resim 7, 8, 9).

Son olarak, kimi çocuk oyunlarının, geçmişte yetişkinlerin ve toplumun ciddi uğraşılarının bir kalıntısı olduğunu hatırlayarak (And, 1979) söz konusu çocuk oyununun büyüklerin ve hatta soyluların oyunu olduğuna dair izlerden de söz edebiliriz: İspanyolların meşhur ressamı Francisco de Goya'nın 1790'lara

\footnotetext{
${ }^{8}$ İbraniler ve Babilliler günah keçisini çöllere sürerlerdi (bkz. Eliade, 1976).
}

${ }^{9}$ bkz. And, 2000, s. 57, 110, 248, 249.

${ }^{10}$ bkz. Yalman, 1993, s. 309-310.
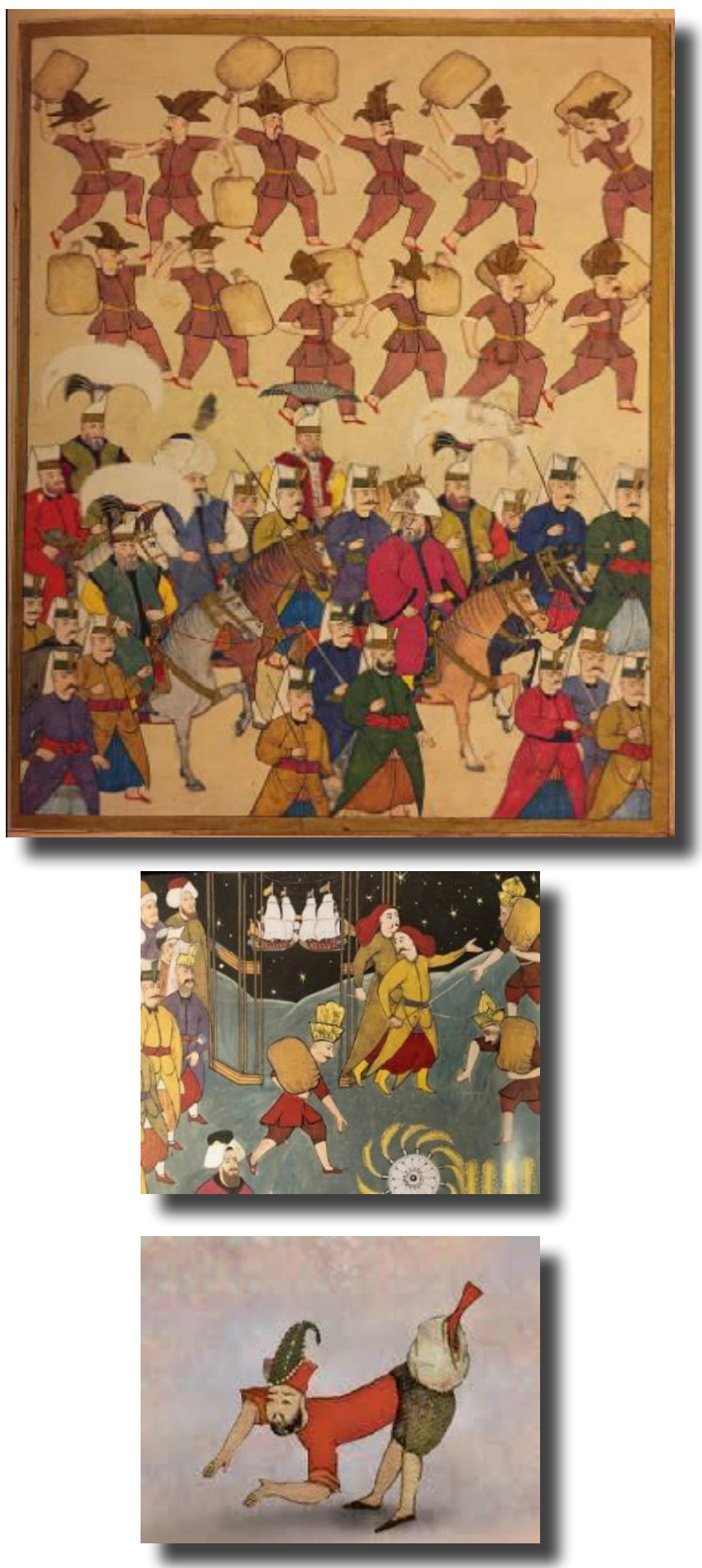

Resim 4, 5, 6. Osmanlı minyatürlerinde tulumcular ve tuluk oyunu

tarihlenen bir tablosunda körebe oyunu resmedilmiştir (Resim 10). "Körebe Oyunu" adlı bu tablo hakkında iki yüzyıl öncesinin İspanyol soylularının oynadığı ve körebenin güzel bir "maja” olduğunda (çıplak ya da giyimli) oyun birdenbire soylu ve erotizm yüklü bir dansa dönüşebileceği yorumları yapılmıştır.

\section{Sonuç}

$\mathrm{Bu}$ sınırlı metinle, dünyanın birçok yerinde kör keçi olarak adlandırılan ve Anadolu'nun bazı bölgelerinde de kör çepiç olarak bilinen körebe oyununa, oyunun 

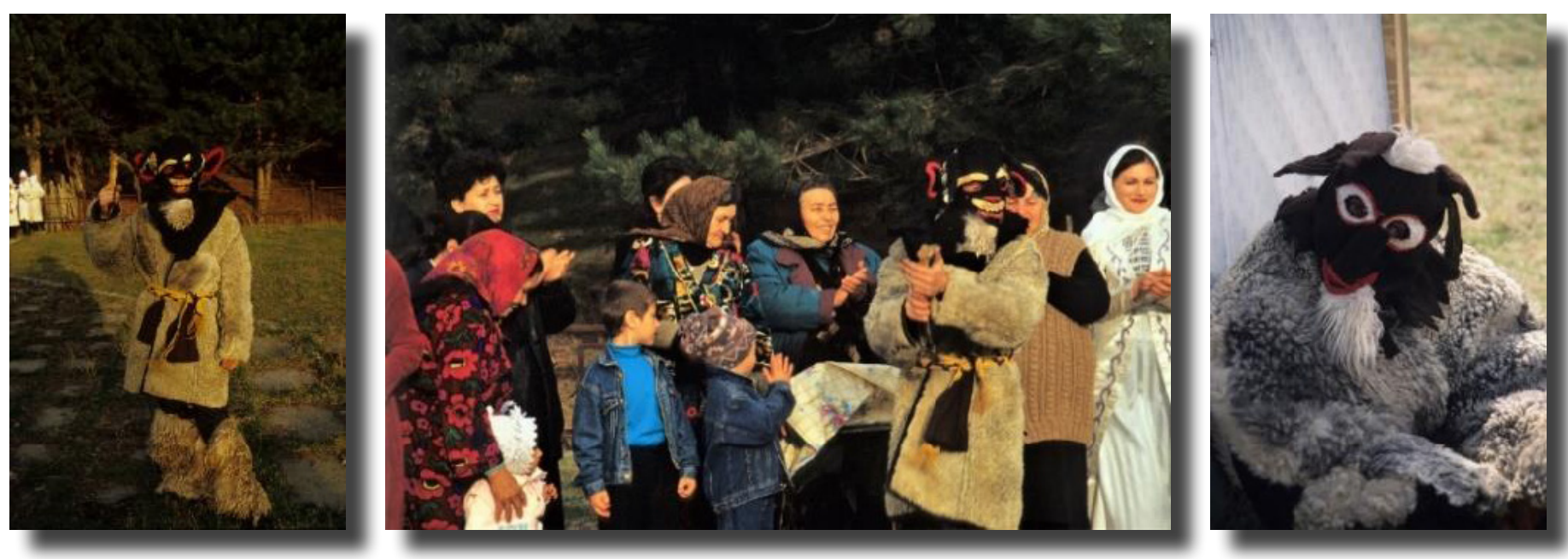

Resim 7, 8, 9. Köy seyirlik oyunlarında keçi (M. Muhtar Kutlu'nun arşivinden)

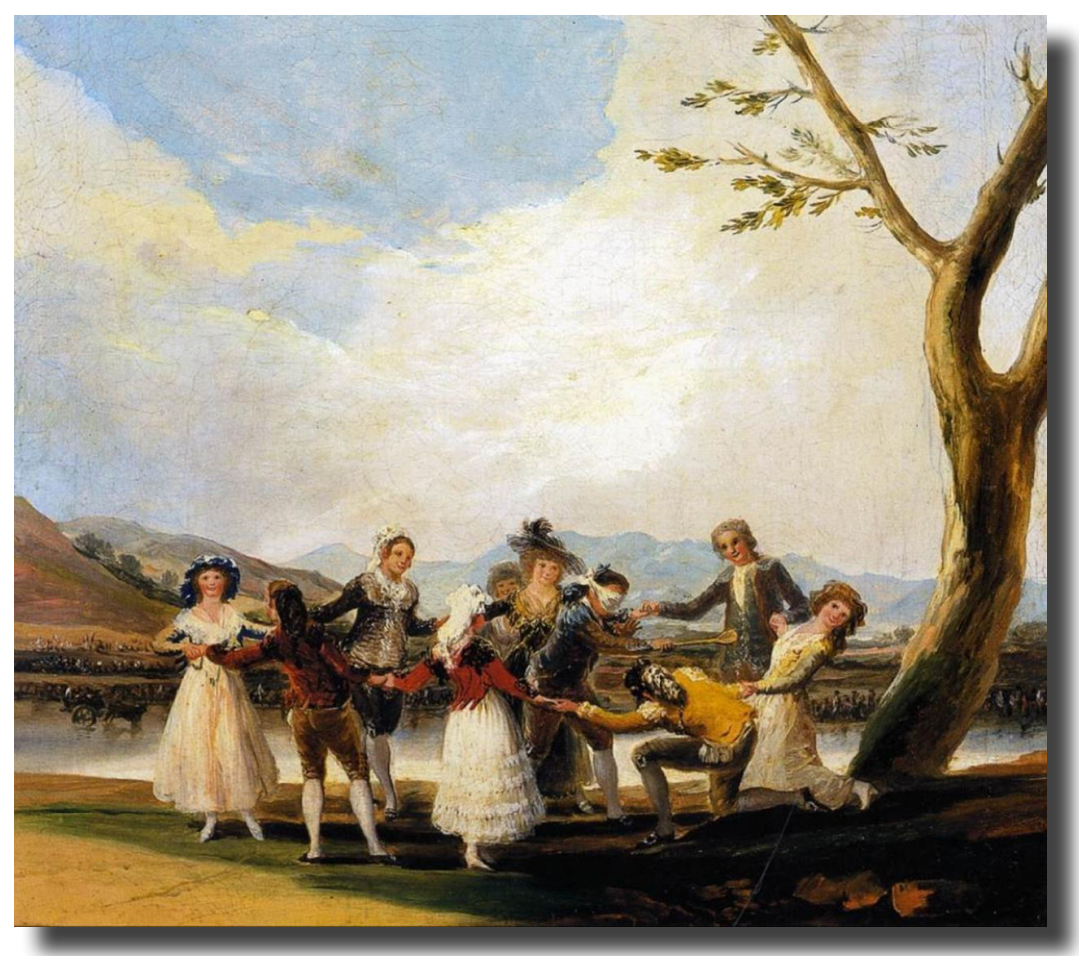

Resim 10. Francisco de Goya y Lucientes - Blind Man's Bluff, 1789

adı, ebenin adlandırılışı ve oyunun dramatik yapısı gibi açılarından bakarak toplumsal bellekte saklı bir ritüel kalıntısı olduğunu gösteren izler üzerinden yürümeye çalıştık. Oyunun sadece bir oyun olmaktan çok, değişime uğramış güçlü ve köklü bir ritüelin oyuna dönüşmüş olduğu anlaşılmaktadır.

Sonuçta, çocuk oyunları çocuğun kültürlenme sürecine katkıları olduğu kadar çocuğun dünyasını, yetişkinlerin dünyasına yaklaştıran, eşitleyen yaklaşımları da sergilemektedir. Bir diğer ifadeyle oyunun, çocuğu yetişkinlerin dünyasına katılmasını sağlayan bir yol olduğu söylenir (And, 1979). Çocuklar, körebe oyunuyla bu kutsal zamanı taklit edercesine yeniden yassıyor ve ebe (kör keçi) yeni kurbanlarını yani günah keçilerini seçiyor olmalı. Çocuk bu kozmogonik uğraşa küçültülmüş bir ölçekte bir çocuk oyunuyla ritüel ve simgesel anlamda doğrudan katılmaktadır. Körebe oyununun, Metin And'in işaret ettiğinin yanı sıra, oyunun basit kurgusuna karşın, çok yönlü, zengin içerikli ve toplumsal bellekte saklı ritüelistik izlerle yüklü olduğu görülmektedir.

\section{Kaynakça}

Aktan, O. (1996). Antalya Çevresinde ve Güney Anadolu'da Depreșen ve Dinen Konar-Göçer Asabiyeti. I. Akdeniz Yöresi Türk Topluluklar Sosyo-Kültürel Yapısı (Yörükler) Sempozyumu Bildirileri (s. 1-23). T. C. Kültür Bakanlığ1 Yayınları.

And, M. (1962). Dionisos ve Anadolu Köylüsü. İstanbul: Elif.

And, M. (1979). Çocuk Oyunlarının Kültürümüzdeki Yeri ve Önemi. Ulusal Kültür, 1(4), 42-66.

And, M. (2000). 40 Gün 40 Gece - Osmanl Dügü̈leri, Şenlikleri, Geçit Alaylar. Toprakbank Yayınları

And, M. (2012). Oyun ve Bügü. Yap1 Kredi Yayınları. 
And, M. (2014). Osmanl Tasvir Sanatlar: Minyatür. Yap1 Kredi Yayınları.

Cengiz, S. (1997). Alan, Zaman, Kurallar ve Amaç Çerçevesinde Oyunun Neliği Üzerine. Folklor/Edebiyat, 11, 53-64.

Çınar, A. A. (2007). Akyaka Sözlü Taribi ve Gökova Havzasi Halk. Kültürü. Akyaka Belediyesi Yayınları.

Çınar, A. A. (2007). Muğla ve Cevresi Sözlü Kültürü ve Toplumsal Değerleri. Muğla Belediyesi Yayınları.

Demircioğlu, Y. Z. (1934). Anadolu'da Eski Coonk Oyunlar. Milli Mecmua Matbaasi.

Eren, A. N. (1984). Çocuk Oyunları. Halk Kültürü, 2, 17-27.

Frazer, J. G. (2017). Altın Dal - Dinin ve Folklorun Kökleri (M. H. Doğan, Çev.). Yapı Kredi Yayınları.

Huizinga, J. (1995). Homo Ludens - Oyunun Toplumsal İslevi Üzerine Bir Deneme. (M. A. Kılıçbay, Çev.). Ayrıntı Yayınları.

Koşay, H. Z. (1935). Ankeara Budun Bilgisi. Ulus Yayınları.

Oyal, Ö. F. (2013). Keçi - Zanl, Kurban, Cefakâr. Yapı Kredi Yayınları.

Özbudun, S. (1997). Ayinden Törene / Siyasal İktidarn Kurulma ve Kurumsallaşma Sürecinde Törenlerin İslevleri. Anahtar Kitaplar.

Özdemir, N. (2006). Türk Çocuk Oyunlar I-II. Akçă̆ Yayınları.

Özhan, M., ve Muradoğlu, M. (1997). Türk Cumburiyetlerinde Cocuk Oyunlar. T. C. Kültür Bakanlığ1 Yayınları.

Turner, V. (2018). Ritüeller - Yapı ve Anti-Yapı. (N. Küçük, çev.). İthaki.

Türk Dil Kurumu (2005). Türkçe Sǫ̈lïk. Türk Dil Kurumu Yayınları. Ün, C. (2014). Keçi Medeniyeti. Ayrıntı Yayınları.

Yalman (Yalg1n), A. R. (1993). Cenupta Türkmen Oymaklar (İkinci Cilt). T. C. Kültür Bakanlığı Yayınları.

\section{Çevrimiçi Kaynakça}

Sending out the scapegoat (t.y.). Canyon-News. https://www canyon-news.com/wp-content/uploads/2016/01/ $\mathrm{Webb}=$ Sending_Out_the_Scapegoat.jpg

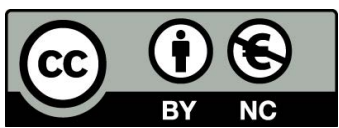

2020. Telif hakları yazar(lar)a aittir.

Bu makale Creative Commons Attf-GayriTicari 4.0 Uluslararası (CC BY-NC 4.0)

lisansının hüküm ve şartları alınnda yayımlanan açık erişimli bir makaledir. 